\title{
Effect of Packaging Method on the Lipid Oxidation, Protein Oxidation, and Color in Aged Top Round from Hanwoo (Korean Native Cattle) during Refrigerated Storage
}

\author{
Sun Moon Kang, Geunho Kang, Pilnam Seong, Beomyoung Park, and Soohyun Cho* \\ Animal Products Research and Development Division, National Institute of Animal Science, \\ Rural Development Administration, Suwon 441-706, Korea
}

\begin{abstract}
The objective of this study was to investigate the effects of the packaging method on the lipid and protein oxidation, and color in aged top round from Hanwoo (Korean native cattle) for $14 \mathrm{~d}$ at $4^{\circ} \mathrm{C}$. Catalase activity was the highest $(p<0.05)$ in vacuum packaging (VP) treatment during storage, and was higher $(p<0.05)$ in 50\% Ox-MAP and 50\% Ox-MAP+vacuum skin packaging (VSP) treatments than in other treatments at $\mathrm{d} 14$. Superoxide dismutase activity was higher $(p<0.05)$ in VP, $50 \%$ Ox-MAP, and 50\% Ox-MAP+VSP treatments than in other treatments at $\mathrm{d} 14$. During storage, total antioxidant activity was the highest $(p<0.05)$ in VP treatment and was higher $(p<0.05)$ in 50\% Ox-MAP+VSP treatment than in $80 \%$ OxMAP treatment. TBARS value was the lowest $(p<0.05)$ in VP treatment during storage and was lower $(p<0.05)$ in $50 \%$ OxMAP and Ox-MAP+VSP treatments than in $80 \%$ Ox-MAP and Ox-MAP treatments, respectively. Carbonyl content was the lowest $(p<0.05)$ in VP treatment from $10 \mathrm{~d}$. From $7 \mathrm{~d}$, the $\mathrm{a}^{*}$ value was the highest $(p<0.05)$ in VP treatment and was higher $(p<0.05)$ in 50\% Ox-MAP and 50\% Ox-MAP+VSP treatments than in other treatments. The $\mathrm{b}^{*}$ value was the highest $(p<0.05)$ in VP treatment from $3 \mathrm{~d}$, and was higher $(p<0.05)$ in $80 \%$ Ox-MAP+VSP, 50\% Ox-MAP, and 50\% Ox-MAP+ VSP treatments than in $80 \%$ Ox-MAP treatment at $\mathrm{d} 14$. Therefore, VP improved the oxidation and red color stabilities in stored-aged top round compared with Ox-MAP. In addition, 50\% Ox-MAP improved the lipid oxidation and red color stabilities compared with $80 \%$ Ox-MAP, and its inhibitory effect on lipid oxidation was enhanced by combination with VSP.
\end{abstract}

Key words: packaging method, lipid oxidation, protein oxidation, color, top round, aged

\section{Introduction}

The proper selection of packaging method is important for preservation of freshness and retardation of decline in quality in the meat products after slaughter and processing. Since 1950's, from hand-wrapped paper to functional materials film packaging, several packaging methods have been developed for consumption and distribution of meat products (Brody, 2002).

Vacuum packaging (VP) and modified atmosphere packaging (MAP) may be the most common packaging methods for storage of fresh meat. VP has strong suppressant effects on oxidation and microbe with condition of little oxygen but leads to the unattractive purple color with

*Corresponding author: Soohyun Cho, Animal Products Research and Development Division, National Institute of Animal Science, RDA, Suwon 441-706, Korea. Tel: +82-31-290-1703, Fax: +82-31-290-1697, E-mail: shc0915@korea.kr high proportion of deoxymyoglobin (Jeremiah, 2001). On the other hand, MAP (particularly, high oxygen $\left(80 \% \mathrm{O}_{2} /\right.$ $20 \% \mathrm{CO}_{2}$ )-MAP) is effective for enhancement of color stability together suppression of microbial growth with filled $\mathrm{O}_{2}$ and $\mathrm{CO}_{2}$ but promotes the oxidative deterioration (Kim et al., 2010; McMillin, 2008; Ordóñez and Ledward, 1977; Silliker and Wolfe, 1980; Sørheim et al., 1997). Furthermore, MAP is mainly applied to display unlike VP that is widely used in all storage systems including aging and freezing.

Recently, vacuum skin packaging (VSP) is also utilized for retail display of meat worldwide. This packaging method has similar properties to VP, MAP, and wrap packaging. The VSP film, which is heat-expansible material, is tightly adhered to the surface of meat on tray by high temperature and vacuum pressure and then is completely stuck to tray. This process can render further enhanced appearance to consumer with prevention of surface air hole and crease, and purge loss when compared with VP 
that causes the losses of water and shape in meat with strong compression (Lagerstedt et al., 2011; Santos et al., 2005; Vázquez et al., 2004). Moreover, some studies have reported that VSP was more effective for betterment of color stability and extension of shelf-life than VP and had similar effect on maintenance of red color to high oxygen-MAP (Barros-Velázquez et al., 2003; Li et al., 2012).

In the meat, lipid oxidation is promoted by storage environments, such as $\mathrm{O}_{2}$ concentration, temperature, light etc. and accelerates the accumulation of metmyoglobin and chemical deterioration of protein with generation of free radicals (Kanner, 1994; Monahan, 2000; Zakrys et al., 2009). Discoloration brings out the consumer's refusal to buy the meat and incurs the economic loss of retail (Greene et al., 1971; Smith et al., 2000). Protein oxidation develops toxic compounds and odor and negatively influences the texture and water-holding capacity by decomposition and denaturation of the meat protein (Davis and Dean, 2003; Morzel et al., 2006; Xiong, 2000). After all, maintenance or enhancement of the oxidative stability could be a key point to conserve the meat quality during storage.

Therefore, we worked to investigate the effect of packaging method on the lipid oxidation, protein oxidation, and color in aged top round from Hanwoo (Korean native cattle) during refrigerated storage.

\section{Materials and Methods}

\section{Reagents and chemicals}

Trizma base, cacodylic acid, diethylenetriaminepentaacetic acid (DTPA), pyrogallol, ethylenediaminetetraacetic acid disodium salt dehydrate (EDTA), glutathione reductase (from Baker's yeast; GSH-R), L-glutathione reduced (GSH), $\beta$-nicotinamide adenine dinucleotide hydrate (NADPH), pipes, potassium ferricyanide, ammonium sulfamate, lead acetate, trichloroacetic acid (TCA), 2,4dinitrophenylhydrazine (DNPH), guanidine hydrochloride, and serum albumin from bovine were purchased from Sigma-Aldrich Co. LLC. (USA). The 2-thiobarbituric acid was purchased from Alfa Aesar (USA). Ethanol, ethyl acetate, and chloroform were obtained from J. T. Baker (USA). Deionized water was made with a Milli-Q Water Purification Equipment (Millipore SAS, France).

\section{Preparation of samples and experimental design}

The top rounds (quality grade : 1) from Hanwoo (Korean native cattle) steers at $2 \mathrm{~d}$ post-slaughter were obtained from a local meat market and aged for $7 \mathrm{~d}$ at $2^{\circ} \mathrm{C}$. Following removal of backfat, connective tissue, and blood, the lean beef were sliced into about $1 \mathrm{~cm}$ thickness and packaged either with; 1) vacuum (VP), 2) $80 \% \mathrm{O}_{2} / 20 \% \mathrm{CO}_{2} /$ $0 \% \mathrm{~N}_{2}$-modified atmosphere (80\% Ox-MAP), 3) vacuum skin $+80 \%$ Ox-MAP (VSP $+80 \%$ Ox-MAP), 4) $50 \% \mathrm{O}_{2} /$ $20 \% \mathrm{CO}_{2} / 30 \% \mathrm{~N}_{2}$-modified atmosphere (50\% Ox-MAP), or 5) vacuum skin $+50 \%$ Ox-MAP (VSP $+50 \%$ Ox-MAP). The VP treatment was packaged with 7 layer co-extrusion films (nylon+tie+LLDPE+tie+nylon+tie+LLDPE; FoodSaver pouch, Rollpack Co., Ltd., Korea) and vacuum packaging machine (CD-120, Webomatic Maschinenfabrik $\mathrm{GmbH}$, Germany). The MAP treatments were packaged with polystyrene barrier foam trays (Max. $\mathrm{O}_{2}$ transmission rate: $0.1 \mathrm{cc} / \mathrm{cm}^{2} \cdot 24 \mathrm{~h}$ at $23^{\circ} \mathrm{C}$, RH $0 \%$, Max. moisture vapor transmission rate $: 7.87 \mathrm{mg} / \mathrm{cm}^{2} \cdot 24 \mathrm{~h}$ at $38^{\circ} \mathrm{C}$, RH 100\%; SCB 00-096, Cryovac Sealed Air Corp., USA), $\mathrm{O}_{2}$ barrier films (Max. $\mathrm{O}_{2}$ transmission rate: 0.002 $\mathrm{cc} / \mathrm{cm}^{2} \cdot 24 \mathrm{~h}$ at $4.4^{\circ} \mathrm{C}$, RH $100 \%$, Max. moisture vapor transmission rate : $0.39 \mathrm{mg} / \mathrm{cm}^{2} \cdot 24 \mathrm{~h}$ at $4.4^{\circ} \mathrm{C}$, RH $100 \%$; Lid 1050, Cryovac Sealed Air Corp., USA), and MAP machine (MAP-RT1, HyperPac Co., Korea) equipped with a gas mixer (MAP Mix $9001 \mathrm{ME}, \mathrm{PBI}$ Dansensor A/S, Ringsted, Denmark). In case of the VSP +MAP treatments, the samples were placed into polystyrene barrier foam trays and then packaged with permeable intact films (100 247492, Cryovac Sealed Air Corp., USA) and vacuum skin packaging machine (VSP-S100, Samhwa Co., Korea) before packaging with MA. All samples were stored for $14 \mathrm{~d}$ at $4^{\circ} \mathrm{C}$ after aging and the experimental parameters were measured at $1,3,7,10$, and $14 \mathrm{~d}$.

\section{Gas composition analysis}

The concentrations (\%) of $\mathrm{O}_{2}$ and $\mathrm{CO}_{2}$ in MAP were analyzed using a portable gas analyzer (OxyBaby $\mathrm{M}+\mathrm{X}$ $\mathrm{O}_{2} / \mathrm{CO}_{2}$, Witt-Gasetechnik GmbH \& Co., KG, Germany). The concentration (\%) of nitrogen was calculated as 100 minus percentages of $\mathrm{O}_{2}$ and $\mathrm{CO}_{2}$.

\section{Analysis of antioxidant enzyme activity}

For analyses of activities of antioxidant enzymes, $5 \mathrm{~g}$ of samples were homogenized with $20 \mathrm{~mL}$ of ice-cold phosphate buffer (50 mM, pH 7.0) using an Ultra-Turrax (T25 Digital, Ika Werke GmbH \& Co., Germany) for $30 \mathrm{~s}$ at $13,500 \mathrm{rpm}$, centrifuged for $15 \mathrm{~min}$ at $2^{\circ} \mathrm{C}, 1,000 \mathrm{~g}$ (Avanti J-E Centrifuge, Beckman Coulter, Inc., USA), and then filtered with Whatman filter paper No. 1. Catalase activity was performed according to the method developed by Aebi (1983). Immediately after mixing $100 \mu \mathrm{L}$ of filtrates with $29 \mathrm{mM} \mathrm{H}_{2} \mathrm{O}_{2}$ (in phosphate buffer, $\mathrm{pH}$ 7.0), the decomposition rate of $\mathrm{H}_{2} \mathrm{O}_{2}$ was spectrophotometrically 
(ProteomeLab DU-800, Beckman Coulter, Inc., USA) analyzed for $30 \mathrm{~s}$ at $240 \mathrm{~nm}$ at $25^{\circ} \mathrm{C}$. Superoxide dismutase activity was conducted as described by Marklund (1986). The inhibition of autooxidation of $0.2 \mathrm{mM}$ pyrogallol (in tris-cacodylate-DTPA buffer, $\mathrm{pH} 8.2$ ) by $50 \mu \mathrm{L}$ of filtrates was monitored for $2 \mathrm{~min}$ at $420 \mathrm{~nm}$ at $25^{\circ} \mathrm{C}$. Glutathione peroxidase (GSH-Px) activity was analyzed following the enzymatic protocol reported by Flohé and Günzler (1984). One hundred milliliters of filtrates were mixed with $1 \mathrm{mM}$ EDTA-1 $\mathrm{mM} \mathrm{NaN}_{3}-0.5$ units/mL GSH-R-1 mM GSH-0.15 mM NADPH-0.15 mM H $\mathrm{H}_{2} \mathrm{O}_{2}$ (in phosphate buffer, $\mathrm{pH}$ 7.0) and then the oxidation rate of NADPH was measured for $3 \mathrm{~min}$ at $340 \mathrm{~nm}$ at $25^{\circ} \mathrm{C}$. The activities of all antioxidant enzymes were expressed with change rates of absorbance per min as units enzyme per $g$ meat.

\section{Total antioxidant activity measurement}

Total antioxidant ability (TAA) was measured with the process slightly modified by Lee et al. (1981). Two grams of samples were homogenized with $10 \mathrm{~mL}$ of ice-cold pipes buffer ( $25 \mathrm{mM}, \mathrm{pH} 5.8$ ) by a Polytron (PT-MR 2100, Kinematica AG, Switzerland) for $15 \mathrm{~s}$ at 13,500 rpm. Following incubation with $2 \mathrm{~mL}$ of potassium ferricyanide (5 $\mathrm{mM}$ ) for $1 \mathrm{~h}$ on an ice under the dark, $5 \mathrm{~mL}$ of homogenates were mixed with $100 \mu \mathrm{L}$ of ammonium sulfamate (40 mM), $200 \mu \mathrm{L}$ of lead acetate $(0.5 \mathrm{M}), 2.5 \mathrm{~mL}$ of TCA $(20 \%(\mathrm{w} / \mathrm{v}))$ and then made up to $10 \mathrm{~mL}$ with DW. The final mixtures were centrifuged for $10 \mathrm{~min}$ at $2^{\circ} \mathrm{C}, 3,000$ g (Avanti J-20XP Centrifuge, Beckman Coulter, Inc., USA) before filtering with Whatman filter paper No. 42 and then measured at $420 \mathrm{~nm}$. The results were expressed as absorbance value of blank ( $1 \mathrm{mM}$ potassium ferricyanide) minus absorbance values of samples.

\section{TBARS value measurement}

The 2-thiobarbituric acid reactive substances (TBARS) value was conducted following the method previously reported by Sinnhuber and Yu (1977). Before heated for $30 \mathrm{~min}$ at $100^{\circ} \mathrm{C}$ and ice-cooled for $10 \mathrm{~min}, 0.5 \mathrm{~g}$ of samples were mixed with about $0.1 \mathrm{~g}$ of antioxidant mixture (54\% $(\mathrm{w} / \mathrm{w})$ propylene glycol-40\% $(\mathrm{w} / \mathrm{w})$ Tween $20-3 \%$ (w/w) BHT-3\% (w/w) BHA), $3 \mathrm{~mL}$ of $1 \%(\mathrm{w} / \mathrm{v})$ TBA$0.3 \%(\mathrm{w} / \mathrm{v}) \mathrm{NaOH}$, and $17 \mathrm{~mL}$ of $2.5 \%(\mathrm{w} / \mathrm{v}) \mathrm{TCA}-36$ $\mathrm{mM} \mathrm{HCl}$. The upper solutions were spectrophotometrically measured at $532 \mathrm{~nm}$ following combined with chloroform and then centrifuged for $30 \mathrm{~min}$ at $3,000 \mathrm{~g}$ at $4^{\circ} \mathrm{C}$ (Avanti J-E Centrifuge, Beckman Coulter, Inc., USA). The TBARS value was expressed as $\mathrm{mg}$ of malonaldehyde (MA) per kg of sample.

\section{Carbonyl content measurement}

The carbonyl content was analyzed with the process established by Mercier et al. (1998). Two grams of samples were homogenized with $20 \mathrm{~mL}$ of ice-cold $\mathrm{KCl}(0.15$ $\mathrm{M})$ and filtered with Whatman filter paper No. 1. One hundred microliters of filtrates were incubated either with $0.5 \mathrm{~mL}$ of $0.2 \%(\mathrm{w} / \mathrm{v}) \mathrm{DNPH}$ (in $2 \mathrm{~N} \mathrm{HCl}$; for carbonyl content) or $2 \mathrm{~N} \mathrm{HCl}$ (for protein content) for $1 \mathrm{~h}$ under the dark, combined with $0.6 \mathrm{~mL}$ of ice-cold $20 \%$ (w/v) TCA, and then placed for $10 \mathrm{~min}$ at $2^{\circ} \mathrm{C}$. After centrifuged for $5 \mathrm{~min}$ at $2^{\circ} \mathrm{C}, 3,000 \mathrm{~g}$ (Microfuge 22R Centrifuge, Beckman Coulter $\mathrm{GmbH}$, Germany), the sediments were rinsed with $50 \%(\mathrm{v} / \mathrm{v})$ ethanol (in ethyl acetate) at three times, dried in a hood, dissolved in $1 \mathrm{~mL}$ of $6 \mathrm{M}$ guanidine hydrochloride (in $0.02 \mathrm{M}$ potassium phosphate, $\mathrm{pH}$ 6.5), and then spectrophotometrically measured at 370 (DNPH-incubated) and 280 (HCl-incubated) nm. The carbonyl content was calculated with millimolar extinction coefficient $\left(22.0 \mathrm{mM}^{-1} \mathrm{~cm}^{-1}\right.$; Reznick and Packer, 1994) and standard curve of bovine serum albumin as nmol carbonyl per mg protein.

\section{Surface color determination}

The color ( $\mathrm{L}^{*}, \mathrm{a}^{*}$, and $\mathrm{b}^{*}$ values) on the surface of samples was determined using a chroma meter (CR-400, Konica Minolta Sensing, Inc., Japan) calibrated with a white plate (illuminant $\mathrm{C} ; \mathrm{L}^{*}=97.70, \mathrm{a}^{*}=-0.05$, and $\mathrm{b}^{*}=1.94$ ). The MAP and VSP+MAP treatments were measured immediately after opening of packs while the VP treatment was measured after blooming of $30 \mathrm{~min}$.

\section{Statistical analysis}

All experimental data during storage times were analyzed by Analysis of Variance (ANOVA) of SPSS (2011) program. By Duncan's multiple range tests, the significant differences among the means of treatments at the same storage time were compared at $p<0.05$.

\section{Results and Discussion}

\section{Antioxidant enzyme activity}

The effect of packaging method on the antioxidant enzyme activity in aged top round from Hanwoo (Korean native cattle) for $14 \mathrm{~d}$ of storage at $4^{\circ} \mathrm{C}$ was indicated in Table 1 . The cattle tissues possess enzymatic antioxidant system, such as catalase, SOD, and GSH-Px etc., which protect against the attacks of free radicals (Chan and Decker, 1994). Even post-slaughter, antioxidant enzymes remain in beef muscles and chiefly work their own bio- 
Table 1. Effect of packaging method on the antioxidant enzyme activity in aged top round from Hanwoo (Korean native cattle) during storage at $4^{\circ} \mathrm{C}$

\begin{tabular}{ccccccc}
\hline \hline Items & Storage time $(\mathrm{d})$ & VP & $80 \%$ Ox-MAP & $80 \%$ Ox-MAP+VSP & $50 \%$ Ox-MAP & $50 \%$ Ox-MAP+VSP \\
\hline Catalase & 1 & $129.49 \pm 14.04^{\mathrm{a}}$ & $91.94 \pm 8.90^{\mathrm{b}}$ & $99.02 \pm 18.88^{\mathrm{b}}$ & $105.51 \pm 10.30^{\mathrm{b}}$ & $101.57 \pm 3.96^{\mathrm{b}}$ \\
(Units/ & 7 & $114.89 \pm 16.86^{\mathrm{a}}$ & $87.23 \pm 6.87^{\mathrm{b}}$ & $86.74 \pm 6.46^{\mathrm{b}}$ & $84.15 \pm 22.45^{\mathrm{b}}$ & $85.96 \pm 18.22^{\mathrm{b}}$ \\
g meat) & 14 & $127.71 \pm 8.53^{\mathrm{a}}$ & $70.35 \pm 15.37^{\mathrm{c}}$ & $81.33 \pm 7.32^{\mathrm{c}}$ & $93.70 \pm 6.57^{\mathrm{b}}$ & $97.87 \pm 9.56^{\mathrm{b}}$ \\
\hline GSH-Px & 1 & $2.13 \pm 0.20$ & $1.98 \pm 0.41$ & $2.22 \pm 0.18$ & $2.14 \pm 0.33$ & $2.28 \pm 0.22$ \\
(Units/ & 7 & $2.33 \pm 0.24$ & $2.16 \pm 0.49$ & $2.30 \pm 0.14$ & $2.11 \pm 0.40$ & $2.01 \pm 0.42$ \\
g meat) & 14 & $2.39 \pm 0.50$ & $2.05 \pm 0.53$ & $2.29 \pm 0.45$ & $2.42 \pm 0.46$ & $2.38 \pm 0.51$ \\
\hline SOD & 1 & $114.46 \pm 10.43$ & $105.07 \pm 15.27$ & $118.47 \pm 3.97$ & $114.80 \pm 9.16$ & $112.24 \pm 5.80$ \\
(Units/ & 7 & $156.46 \pm 5.34$ & $135.07 \pm 13.21$ & $139.39 \pm 14.27$ & $147.55 \pm 6.84$ & $149.08 \pm 11.68$ \\
g meat) & 14 & $120.61 \pm 6.30^{\mathrm{a}}$ & $101.19 \pm 7.06^{\mathrm{b}}$ & $110.20 \pm 10.09^{\mathrm{b}}$ & $123.74 \pm 11.35^{\mathrm{a}}$ & $120.95 \pm 5.84^{\mathrm{a}}$ \\
\hline
\end{tabular}

${ }^{a-c}$ Means \pm S.D. in the same row with different superscripts differ significantly $(p<0.05)$.

logical functions at the first phase in oxidation processes (Halliwell and Gutteridge, 1989; Renerre et al., 1996). Catalase (hydrogen peroxide: hydrogen peroxide oxidoreductase; E.C. 1.11.1.6) is a tetrameric haemin enzyme which subsists in all living creatures and aerobic microorganism and has much higher activity (decomposition of $10^{6} \mathrm{H}_{2} \mathrm{O}_{2}$ per $1 \mathrm{~s}$ ) compared with other enzymes (Aebi, 1983). During storage, VP treatment had significantly $(p<0.05)$ the highest catalase activity. The 50\% Ox-MAP and 50\% Ox-MAP+VSP treatments showed significantly $(p<0.05)$ higher catalase activity at $\mathrm{d} 14$ compared with $80 \%$ Ox-MAP and $80 \%$ Ox-MAP+VSP treatments. There were not significant differences for catalase activity by packaging with or without VSP within OxMAP treatments of same $\mathrm{O}_{2}$ concentration. GSH-Px (glutathione: hydrogen peroxide oxidoreductase; E.C. 1.11.1. 9) is a selenoprotein enzyme containing a selenium and prevents the oxidative harm by deoxidization of $\mathrm{H}_{2} \mathrm{O}_{2}$ and lipid hydroperoxides (Flohé and Günzler, 1984). It did not show any difference among all treatments for $14 \mathrm{~d}$. SOD (superoxide: superoxide oxidoreductase; E.C. 1.15.1. 1) includes the $\mathrm{Cu}, \mathrm{Zn}$, and $\mathrm{Mn}$ etc. as co-factors and reduces two superoxide anion $\left(\mathrm{O}_{2}^{-}\right)$molecules into one $\mathrm{H}_{2} \mathrm{O}_{2}$ molecule (Marklund, 1986). At d 14, VP, 50\% OxMAP, and 50\% Ox-MAP+VSP treatments presented significantly $(p<0.05)$ higher than $80 \%$ Ox-MAP and $80 \%$ Ox-MAP+VSP treatments. SOD activity did not also indicate significant differences between Ox-MAP and OxMAP+VSP treatments during storage. Thus, VP and 50\% Ox-MAP with or without VSP maintained higher levels for activities of some antioxidant enzymes in the aged top round during refrigerated storage than $80 \%$ Ox-MAP with or without VSP. This finding is supported by a report of Kang et al. (2012), who found that the activity of some antioxidant enzyme was kept higher by lower $\mathrm{O}_{2}$ concentration in the beef packaged with $0-75 \%$ Ox-MA for $8 \mathrm{~d}$ of storage at $15^{\circ} \mathrm{C} / \mathrm{RH} 100 \%$.

\section{Total antioxidant activity}

The effect of packaging method on the total antioxidant activity (TAA) in aged Hanwoo top round during storage is presented in Fig. 1. TAA is an assay to evaluate the ability which the meat reduce ferrous ions $\left(\mathrm{Fe}^{3+}\right)$ to ferric ions $\left(\mathrm{Fe}^{2+}\right)$ (Lee et al., 1981). VP treatment had significantly $(p<0.05)$ the highest TAA during $14 \mathrm{~d}$ of storage. The 50\% Ox-MAP + VSP treatment maintained significantly $(p<0.05)$ higher TAA for $14 \mathrm{~d}$ compared with $80 \%$ Ox-MAP treatment and had higher $(p<0.05)$ TAA than $80 \%$ Ox-MAP treatment at only d 1 . The $50 \%$ Ox-MAP treatment tended to have higher TAA than $80 \%$ Ox-MAP but showed the significantly $(p<0.05)$ higher value at only $7 \mathrm{~d}$. During storage, there were not significant differences for TAA between Ox-MAP and Ox-MAP+VSP treatments within MAP treatments of same $\mathrm{O}_{2}$ concentration. Thus, VP and 50\% Ox-MAP with or without VSP kept higher TAA in the stored-aged top round compared with high Ox-MAP ( $80 \%$ Ox-MAP) with or without VSP. This

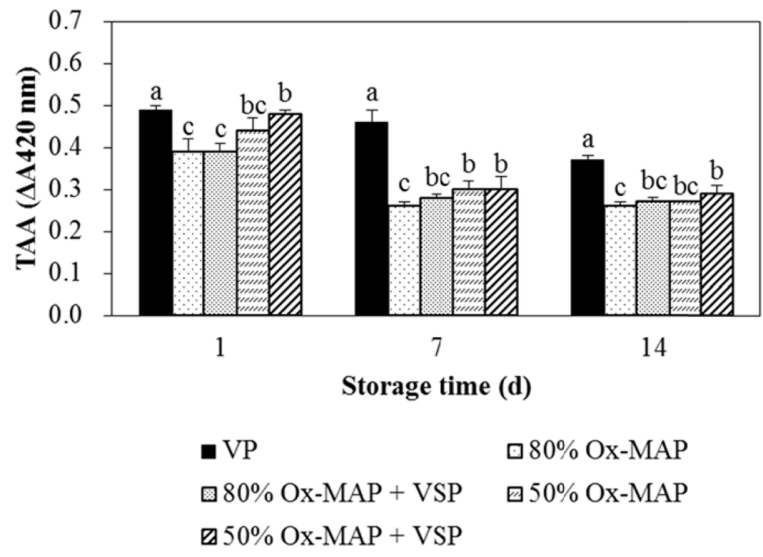

Fig. 1. Effect of packaging method on the total antioxidant activity (TAA) in aged top round from Hanwoo (Korean native cattle) during storage at $4^{\circ} \mathrm{C}$. Values are means \pm S.D. ${ }^{a-c}$ Different letters indicate significant differences among packaging methods within the same storage time $(p<0.05)$. 
result is similar to a previous research of Seyfert et al. (2012), who observed that the beef packaged with $20 \%$ Ox-MA had higher total reducing ability than $80 \%$ Ox$\mathrm{MA}$ in $7 \mathrm{~d}$ of retail display.

\section{TBARS value}

During storage, the value of TBARS (Fig. 2) was significantly $(p<0.05)$ the lowest in VP treatment. The 50\% Ox-MAP+VSP treatment had significantly $(p<0.05)$ lower TBARS value from 7 and $10 \mathrm{~d}$ than $80 \%$ Ox-MAP and $80 \%$ Ox-MAP+VSP treatments and also showed lower $(p<0.05)$ TBARS value than 50\% Ox-MAP treatment at $\mathrm{d}$ 14. The $80 \%$ Ox-MAP+VSP treatment presented lower $(p<0.05)$ TBARS value compared with $80 \%$ Ox-MAP treatment at d 14. Thus, VP and 50\% Ox-MAP inhibited the lipid oxidation in the stored-aged top round compared with $80 \%$ Ox-MAP. This result is in agreement with the result of Zakrys et al. (2009) who reported that the beef packaged with $80 \%$ Ox-MA had the higher TBARS value in $12 \mathrm{~d}$ of storage at $4^{\circ} \mathrm{C}$ compared with $40,50,60,70 \%$ Ox-MA. In addition, in our study, combination of OxMAP and VSP retarded the lipid oxidation by Ox-MAP. This may be because VSP had the similar vacuum effect to VP and slightly prevented the direct contact bet- ween beef and $\mathrm{O}_{2}$ in $\mathrm{Ox}-\mathrm{MA}$.

\section{Carbonyl content}

Free radicals originated from oxidation processes oxidize the meat protein, leading to production of carbonyls (Davis and Dean, 2003). As shown in Fig. 3, VP treatment presented significantly $(p<0.05)$ lower carbonyl content from $10 \mathrm{~d}$ than Ox-MAP and Ox-MAP+VSP treatments.

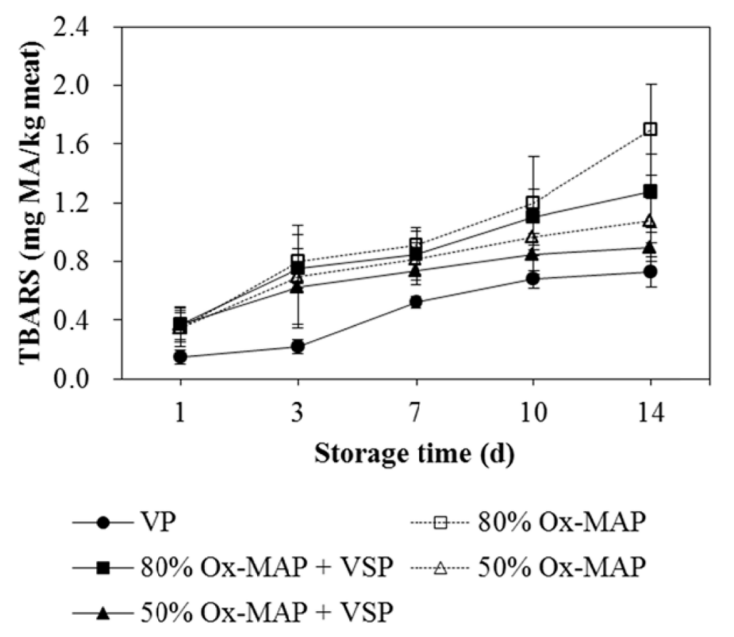

Fig. 2. Effect of packaging method on the TBARS value in aged top round from Hanwoo (Korean native cattle) during storage at $4^{\circ} \mathrm{C}$. Values are means \pm S.D.
The 50\% Ox-MAP and 50\% Ox-MAP+VSP treatments indicated a tendency to have lower carbonyl content during storage compared with $80 \%$ Ox-MAP and $80 \%$ OxMAP+VSP treatments. However, no significant differences were observed for carbonyl content among OxMAP and Ox-MAP+VSP treatments during storage. Similarly, Lund et al. (2007a) reported that 100\% $\mathrm{N}_{2}$-MAP delayed the generation of carbonyl in the beef for $6 \mathrm{~d}$ of storage at $4^{\circ} \mathrm{C}$ compared with $80 \%$ Ox-MAP. Besides, they found that there were not significant differences for carbonyl content between the beef packaged with vacuum skin and $70 \% \mathrm{Ox}-\mathrm{MA}$ for $14 \mathrm{~d}$ of storage at $4^{\circ} \mathrm{C}$ (Lund et al., 2007b).

\section{Surface color}

The effect of packaging method on the surface color during storage is indicated in Table 2 . At only $\mathrm{d} 10$, the $\mathrm{L}^{*}$ value was higher $(p<0.05)$ in $80 \%$ Ox-MAP treatment than in other treatments but did not present a certain tendency by packaging method during storage. From $7 \mathrm{~d}$ of storage, the $\mathrm{a}^{*}$ value was significantly $(p<0.05)$ the highest in VP treatment and was also higher $(p<0.05)$ in $50 \%$ Ox-MAP and 50\% Ox-MAP+VSP treatments compared with $80 \%$ Ox-MAP and $80 \%$ Ox-MAP+VSP treatments. The $\mathrm{b}^{*}$ value was significantly $(p<0.05)$ the highest in VP treatment from $3 \mathrm{~d}$. At the last day, 80\% Ox-MAP+VSP, 50\% Ox-MAP, and 50\% Ox-MAP+VSP treatments had significantly $(p<0.05)$ higher level at the last day compared with $80 \%$ Ox-MAP treatment. Thus, in aged top round, VP and 50\% Ox-MAP with or without VSP maintained higher level for red color during storage compared with $80 \%$ Ox-MAP with or without VSP. This finding is

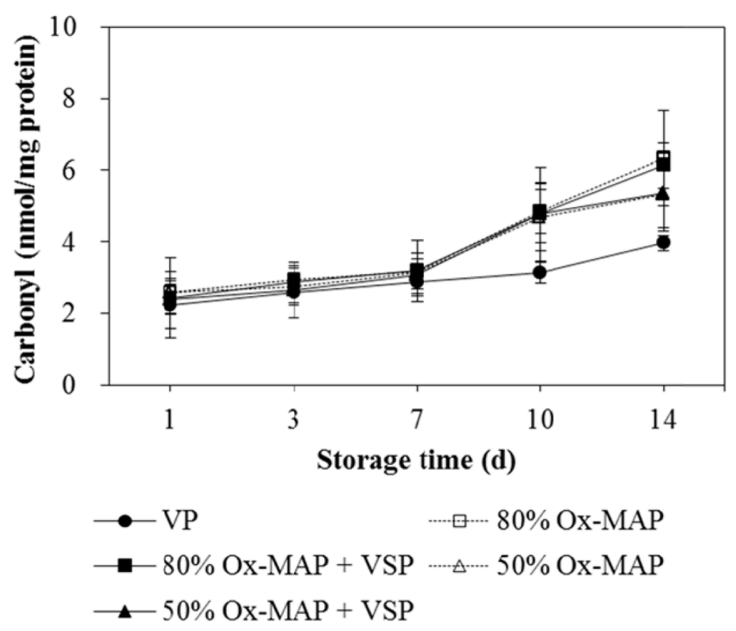

Fig. 3. Effect of packaging method on the carbonyl content in aged top round from Hanwoo (Korean native cattle) during storage at $4^{\circ} \mathrm{C}$. Values are means \pm S.D. 
Table 2. Effect of packaging method on the surface color in aged top round from Hanwoo (Korean native cattle) during storage at $4^{\circ} \mathrm{C}$

\begin{tabular}{|c|c|c|c|c|c|c|}
\hline Items & Storage time $(\mathrm{d})$ & $\overline{\mathrm{VP}}$ & $80 \%$ Ox-MAP & $80 \%$ Ox-MAP+VSP & $50 \%$ Ox-MAP & $50 \%$ Ox-MAP+VSP \\
\hline \multirow{5}{*}{$\mathrm{L}^{*}$} & 1 & $42.66 \pm 3.68$ & $44.93 \pm 1.68$ & $44.77 \pm 3.14$ & $43.97 \pm 1.35$ & $43.28 \pm 1.94$ \\
\hline & 3 & $43.72 \pm 1.90$ & $43.89 \pm 2.00$ & $43.48 \pm 1.47$ & $42.49 \pm 1.36$ & $43.04 \pm 2.11$ \\
\hline & 7 & $43.38 \pm 2.79$ & $43.46 \pm 1.82$ & $45.16 \pm 3.49$ & $46.48 \pm 3.84$ & $43.18 \pm 2.30$ \\
\hline & 10 & $39.79 \pm 1.73^{\mathrm{c}}$ & $45.26 \pm 2.20^{\mathrm{a}}$ & $42.91 \pm 1.68^{\mathrm{b}}$ & $43.51 \pm 1.93^{\mathrm{b}}$ & $42.94 \pm 1.60^{\mathrm{b}}$ \\
\hline & 14 & $44.04 \pm 2.28$ & $45.75 \pm 2.06$ & $44.98 \pm 2.80$ & $45.48 \pm 3.34$ & $45.60 \pm 2.72$ \\
\hline \multirow{5}{*}{$a^{*}$} & 1 & $24.86 \pm 0.79$ & $24.28 \pm 1.64$ & $23.55 \pm 2.07$ & $23.01 \pm 2.55$ & $24.04 \pm 1.03$ \\
\hline & 3 & $23.41 \pm 1.97^{b}$ & $24.20 \pm 1.21^{\mathrm{a}}$ & $24.48 \pm 1.22^{\mathrm{a}}$ & $24.80 \pm 2.25^{\mathrm{a}}$ & $24.70 \pm 1.29^{\mathrm{a}}$ \\
\hline & 7 & $24.39 \pm 2.65^{\mathrm{a}}$ & $21.47 \pm 1.53^{\mathrm{c}}$ & $21.31 \pm 2.37^{\mathrm{c}}$ & $23.02 \pm 1.94^{b}$ & $22.14 \pm 1.87^{b}$ \\
\hline & 10 & $24.48 \pm 1.15^{\mathrm{a}}$ & $17.90 \pm 1.60^{\mathrm{c}}$ & $18.22 \pm 1.21^{\mathrm{c}}$ & $19.05 \pm 1.98^{b}$ & $19.36 \pm 1.85^{b}$ \\
\hline & 14 & $22.16 \pm 4.80^{\mathrm{a}}$ & $13.23 \pm 2.79^{c}$ & $13.36 \pm 1.25^{\mathrm{c}}$ & $14.49 \pm 1.66^{\mathrm{b}}$ & $14.85 \pm 1.69^{\mathrm{b}}$ \\
\hline \multirow{5}{*}{$b^{*}$} & 1 & $11.42 \pm 0.73^{\mathrm{b}}$ & $10.57 \pm 1.27^{\mathrm{c}}$ & $10.19 \pm 0.98^{c}$ & $10.06 \pm 1.45^{\mathrm{c}}$ & $12.37 \pm 0.65^{\mathrm{a}}$ \\
\hline & 3 & $11.06 \pm 1.65^{\mathrm{a}}$ & $10.08 \pm 0.68^{b}$ & $10.40 \pm 0.78^{\mathrm{b}}$ & $10.41 \pm 1.39^{\mathrm{b}}$ & $10.98 \pm 0.64^{\mathrm{b}}$ \\
\hline & 7 & $11.72 \pm 1.45^{\mathrm{a}}$ & $8.94 \pm 0.90^{\mathrm{d}}$ & $9.65 \pm 0.66^{\mathrm{c}}$ & $10.32 \pm 0.91^{\mathrm{b}}$ & $9.63 \pm 0.97^{\mathrm{c}}$ \\
\hline & 10 & $10.91 \pm 0.71^{\mathrm{a}}$ & $7.94 \pm 0.68^{\mathrm{b}}$ & $8.18 \pm 0.88^{b}$ & $7.71 \pm 0.55^{\mathrm{b}}$ & $7.90 \pm 0.89^{\mathrm{b}}$ \\
\hline & 14 & $11.42 \pm 0.85^{\mathrm{a}}$ & $6.87 \pm 0.69^{c}$ & $7.42 \pm 1.49^{\mathrm{b}}$ & $7.58 \pm 1.26^{\mathrm{b}}$ & $7.75 \pm 1.25^{\mathrm{b}}$ \\
\hline
\end{tabular}

${ }^{a-c}$ Means \pm S.D. in the same row with different superscripts differ significantly $(p<0.05)$.

supported by a previous research of Faustman and Cassens (1990) who reported that the discoloration of meat is promoted by lipid oxidation. Our result is agreement with the finding of Kim et al. (2010) who observed that the beef stored with VP maintained higher $\mathrm{a}^{*}$ value for $9 \mathrm{~d}$ at $1-3^{\circ} \mathrm{C}$ compared with $80 \%$ Ox-MAP. As well, Kang et al. (2012) also reported that high $\mathrm{O}_{2}$ concentration in MAP accelerated the decrease of red color in the beef during storage. However, the finding from this study is contrary to previous studies (Barros-Velázquez et al., 2003; Li et al., 2012) observed that the beef stored with VSP had higher color stability than VP. This is because our study made use of VSP film with higher $\mathrm{O}_{2}$ transmission rate $\left(\mathrm{O}_{2}\right.$ permeable $)$ than theirs.

\section{Conclusion}

In this study, VP was the most effective for inhibition of lipid and protein oxidation and preservation of red color. This may be due to stabilization of antioxidant enzyme and maintenance of total antioxidant activity. The $50 \%$ Ox-MAP also retarded the lipid oxidation and discoloration with stabilization of antioxidant enzyme compared with $80 \%$ Ox-MAP. In addition, combination with Ox-MAP and VSP lowered the lipid oxidation by OxMAP. But VSP had lower inhibitory effect on oxidative deterioration than VP due to being packaged with $\mathrm{O}_{2}$ permeable film.

\section{Acknowledgements}

This study was supported by 2013 year Postdoctoral
Fellowship Program (Project No. PJ907000022013) of National Institute of Animal Science, Rural Development Administration, Republic of Korea.

\section{References}

1. Aebi, H. E. (1983) Catalase. In: Methods of enzymatic analysis. Bergmeyer, H. U., Bergmeyer, J., and Graâl, M. (eds), Verlag Chemie GmbH, Weinheim, Germany, pp. 273-286.

2. Barros-Velázquez, J., Carreira, L., Franco, C., Vázquez, B. I., Fente, C., and Cepeda, A. (2003) Microbiological and physicochemical properties of fresh retail cuts of beef packaged under an advanced vacuum skin system and stored at $4{ }^{\circ} \mathrm{C} . J$. Food Prot. 66, 2085-2092.

3. Brody, A. L. (2002) Meat packaging: past, present and future. 55th reciprocal meat conference, East Lansing, Michigan, USA.

4. Chan, K. M. and Decker, E. A. (1994) Endogenous skeletal muscle antioxidants. Crit. Rev. Food Sci. Nutr. 34, 403-426.

5. Davis, M. J. and Dean, R. T. (2003) Radical-mediated protein oxidation. Oxford Science Univ., London, England, pp. 215.

6. Faustman, C. and Cassens, R. G. (1990) The biochemical basis for discoloration in fresh meat: a review. J. Muscle Foods 1, 217-243.

7. Flohé, L. and Günzler, W. A. (1984) Assays of glutathione peroxidase. In: Methods in enzymology. Packer, L. (ed), Academic Press, Inc., London, UK, pp. 114-121.

8. Greene, B. E., Hsin, I., and Zipser, M. W. (1971) Retardation of oxidative color changes in raw ground beef. J. Food Sci. 36, 940-942.

9. Halliwell, B. and Gutteridge, J. M. C. (1989) Free radicals in biology and medicine. 2nd ed, Clarendon Press, Oxford, UK, pp. 144.

10. Jeremiah, L. E. (2001) Packaging alternatives to deliver fresh meats using short- or long-term distribution. Food Res. Int. 34, 749-772. 
11. Kang, S. M., Muhlisin, Kim, G. Y., Cho, S., Park, B., Jung, S., and Lee, S. K. (2012) Relationship of antioxidant enzyme activity, lipid oxidation, and aroma pattern of Hanwoo (Korean cattle) beef under oxidation-promoted condition. Korean $J$. Food Sci. An. 32, 346-353.

12. Kanner, J. (1994) Oxidative processes in meat and meat products: quality implications. Meat Sci. 36, 169-189.

13. Kim, Y. H., Huff-Lonergan, E., Sebranek, J. G., and Lonergan, S. M. (2010) High-oxygen modified atmosphere packaging system induces lipid and myoglobin oxidation and protein polymerization. Meat Sci. 85, 759-767.

14. Lagerstedt, A., Ahnström, M. L., and Lundström, K. (2011) Vacuum skin pack of beef - A consumer friendly alternative. Meat Sci. 88, 391-396.

15. Lee, M., Cassens, R. G., and Fennema, O. R. (1981) Effect of meat ions on residual nitrite. J. Food Proc. Preserv. 5, 191205.

16. Li, X., Lindahl, G., Zamaraskaia, G., and Lundström, K. (2012) Influence of vacuum skin packaging on color stability of beef longissimus lumborum compared with vacuum and high-oxygen modified atmosphere packaging. Meat Sci. 92, 604-609.

17. Lund, M. N., Hviid, M. S., and Skibsted, L. H. (2007a) The combined effect of antioxidants and modified atmosphere packaging on protein and lipid oxidation in beef patties during chill storage. Meat Sci. 76, 226-233.

18. Lund, M. N., Lametsch, R., Hviid, M. S., Jensen, O. N., and Skibsted, L. H. (2007b) High-oxygen packaging atmosphere influences protein oxidation and tenderness of porcine longissimus dorsi during chill storage. Meat Sci. 77, 295-303.

19. Marklund, S. L. (1986) Pyrogallol autooxidation. In: CRC handbook of methods for oxygen radical research. Green, R. A. (ed), CRC Press, Boca Raton, USA, pp. 243-247.

20. McMillin, K. W. (2008) Where is MAP going? A review and future potential of modified atmosphere packaging for meat. Meat Sci. 80, 43-65.

21. Mercier, Y., Gatellier, P., Viau, M., Remignon, H., and Renerre, M. (1998) Effect of dietary fat and vitamin E on colour stability and on lipid and protein oxidation in turkey meat during storage. Meat Sci. 48, 301-318.

22. Monahan, F. J. (2000) Oxidation of lipids in muscle foods: fundamental and applied concerns. In: Antioxidants in muscle foods: nutritional strategies to improve quality. Decker, E. A., Faustman, C., and Lopez-Bote, C. J. (eds), John Wiley \& Sons, Inc., NY, USA, pp. 3-23.

23. Morzel, M., Gatellier, Ph., Sayd, T., Renerre, M., and Laville, E. (2006) Chemical oxidation dcreases proteolytic susceptibility of skeletal muscle myofibrillar proteins. Meat Sci. 73, 536-543.

24. Ordóñez, J. A. and Ledward, D. A. (1977) Lipid and myoglobin oxidation in pork stored in oxygen- and carbon dioxide- enriched atmospheres. Meat Sci. 1, 41-48.

25. Renerre, M., Dumont, F., and Gatellier, Ph. (1996) Antioxidant enzyme activities in beef in relation to oxidation of lipid and myoglobin. Meat Sci. 43, 111-121.

26. Reznick, A. Z. and Packer, L. (1994) Oxidative damage to proteins: Spectrophotometric method for carbonyl assay. In: Methods in enzymology (Oxygen radicals in biological systems). Packer. L. (ed), Academic Press, Inc., San Diego, USA, Vol. 233, pp. 357-363.

27. Santos, E. M., Diez, A. M., González-Fernández, C., Jaime, I., and Rovira, J. (2005) Microbiological and sensory changes in "Morcilla de Burgos" preserved in air, vacuum and modified atmosphere packaging. Meat Sci. 71, 249-255.

28. Seyfert, M., Mancini, R. A., Hunt, M. C., Tang, J., and Faustman, C. (2007) Influence of carbon monoxide in package atmospheres containing oxygen on colour, reducing activity, and oxygen consumption of five bovine muscles. Meat Sci. 75, 432-442.

29. Silliker, J. H. and Wolfe, S. K. (1980) Microbiological safety considerations in controlled atmosphere storage of meats. Food Technol. 34, 59-63.

30. Sinnhuber, R. O. and Yu, T. C. (1977) The 2-thiobarbituric acid reaction, an objective measure of the oxidative deterioration occurring in fats and oils. J. Jpn. Soc. Fish. Sci. 26, 259267.

31. Smith, G. C., Belk, K. E., Sofos, J. N., Tatum, J. D., and Williams, S. N. (2000) Economic implications of improved color stability in beef. In: Antioxidants in muscle foods: nutritional strategies to improve quality. Decker, E. A., Faustman, C., and Lopez-Bote, C. J. (eds), John Wiley \& Sons, Inc, NY, USA, pp. 397-426.

32. Sørheim, O., Aune, T., and Nesbakken, T. (1997) Technological, hygienic and toxicological aspects of carbon monoxide used in modified-atmosphere packaging of meat. Trend Food Sci. Technol. 8, 307-312.

33. SPSS (2011) PASW Statistics 21. Statistical Package for the Social Sciences Incorporated, Illinois, USA.

34. Vázquez, B. I., Carreira, L., Franco, C., Fente, C., Cepeda, A., and Velázquez, J. B. (2004) Shelf life extension of beef retail cuts subjected to an advanced vacuum skin packaging system. Eur. Food Res. Technol. 218, 118-122.

35. Xiong, Y. L. (2000) Protein oxidation and implications for muscle food quality. In: Antioxidants on muscle foods. Decker, E., Faustman, C., and Lopez-Bote, C. (eds), John Wiley and Sons, Inc., NY, USA, pp. 85-111.

36. Zakrys, P. I., O'Sullivan, M. G., Allen, P., and Kerry, J. P. (2009) Consumer acceptability and physicochemical characteristics of modified atmosphere packed beef steaks. Meat Sci. 81, 720-725.

(Received 2014.2.17/Revised 2014.3.16/Accepted 2014.4.4) 